\title{
Electronic Word-of-Mouth Turis Muslim Mengenai Pariwisata Halal di Lombok, Nusa Tenggara Barat, Indonesia
}

\author{
Dhyayi Warapsari ${ }^{1}{ }^{*}$, Effy Zalfiana Rusfian ${ }^{2}$ \\ 1 Universitas Indonesia, Indonesia; dhyayi.warapsari@gmail.com \\ 2 Universitas Indonesia, Indonesia; effy_rusf@yahoo.co.id \\ * Correspondence
}

Received: 2021-01-04; Accepted: 2021-04-07; Published: 2021-05-19

\begin{abstract}
Electronic word-of-mouth (eWOM) communication from tourists that have visited a destination can be used as promotional media for that destination, including in the halal tourism context. Understanding the drivers of Muslim tourist's eWOM is necessary to be able to use eWOM as a means of promoting halal tourism in Indonesia. This research aims to analyze the direct effects of Islamic religiosity, perceived values, and destination satisfaction on eWOM; the mediating effects of destination satisfaction on the link between Islamic religiosity, perceived value, and eWOM; the serial mediating effect of perceived Islamic values and destination satisfaction on the link between Islamic religiosity and eWOM; and comparing the effects of perceived value dimensions, i.e., quality, price, emotional, social, different experience, novelty, safety, location, physical attributes, and nonphysical attributes, on eWOM. This research used the positivism paradigm and quantitative method. The population was Indonesian Muslim tourists who have visited halal tourism destination in Lombok, West Nusa Tenggara. Purposive and snowball sampling methods were used to select samples. The data were collected from 332 respondents via an online survey and analyzed using Partial Least Squares Structural Equation Modeling (PLS-SEM) method. This research found that only perceived social value that has a significant effect on eWOM, while Islamic religiosity, the other dimensions of perceived value, and destination satisfaction are not the direct and indirect drivers of eWOM. The difference in the significance of the effects of those factors can be associated with the origin and age of the respondents, as well as the location of the destination.
\end{abstract}

Keywords: Destination satisfaction; electronic word-of-mouth (eWOM); halal tourism; Islamic religiosity; Muslim tourist; perceived value.

Abstrak: Komunikasi electronic word-of-mouth (eWOM) dari para turis yang pernah berwisata di suatu destinasi dapat menjadi sarana promosi bagi destinasi wisata tersebut, termasuk pada destinasi pariwisata halal. Ada beberapa faktor yang dapat mendorong eWOM turis muslim. Penelitian ini bertujuan untuk menganalisis faktor-faktor religiositas Islami, persepsi nilai, dan kepuasan destinasi terhadap eWOM. Dimensi-dimensi persepsi nilai yang dianalisis dalam penelitian ini adalah kualitas, harga, emosional, sosial, pengalaman baru, pengalaman berbeda, keamanan, lokasi, atribut fisik, dan atribut nonfisik. Penelitian ini menggunakan paradigma positivis dan metode kuantitatif. Populasi penelitian adalah turis muslim Indonesia yang pernah berwisata di destinasi wisata halal di Lombok, Nusa Tenggara Barat. Pengambilan sampel menggunakan teknik purposive sampling dan snowball sampling. Data diperoleh dari 332 responden melalui kuesioner online dan dianalisis dengan metode Partial Least Squares Structural Equation Modeling (PLS-SEM). Penelitian ini menemukan bahwa hanya persepsi nilai sosial yang berpengaruh signifikan terhadap eWOM, sedangkan religiositas Islami, kualitas, harga, emosional, pengalaman baru, pengalaman berbeda, keamanan, lokasi, atribut fisik, atribut nonfisik, dan kepuasan destinasi bukan merupakan faktor pendorong eWOM turis muslim Indonesia, baik secara langsung maupun melalui mediasi. Perbedaan signifikansi pengaruh faktor-faktor tersebut dapat dikaitkan dengan latar belakang asal dan usia responden, serta lokasi destinasi wisata.

Kata Kunci: electronic word-of-mouth (eWOM), kepuasan destinasi, pariwisata halal, persepsi nilai, religiositas Islami, turis muslim. 


\section{Pendahuluan}

Potensi yang dimiliki oleh turis muslim mendorong perkembangan pariwisata halal di berbagai negara dan memunculkan kompetisi antarnegara untuk menarik perhatian turis muslim, termasuk turis muslim asal Indonesia (Battour \& Ismail, 2016; Samori, Md Salleh, \& Khalid, 2016). Pariwisata halal merupakan pasar pariwisata yang berusaha menyediakan fasilitas dan kegiatan wisata yang diperbolehkan oleh ajaran agama Islam (Battour \& Ismail, 2016). Konsumen dalam pasar tersebut merupakan turis muslim yang cenderung memiliki tingkat religiositas tinggi karena turis tersebut menjadikan nilai-nilai keagamaan sebagai dasar pengambilan keputusan wisata dan berperilaku (Abror, Patrisia, Trinanda, Omar, \& Wardi, 2021; Boğan \& Sarışık, 2019; Rodrigo \& Turnbull, 2019). Meskipun demikian, turis muslim Indonesia memiliki kecenderungan untuk menganggap produk wisata di daerah Indonesia yang berpenduduk mayoritas muslim sebagai produk halal secara otomatis sehingga turis muslim Indonesia merasa aman dan tidak terlalu kritis dengan aspek kehalalan produk tersebut (Hamzana, 2017; Pratiwi, Dida, \& Sjafirah, 2018). Pemahaman terhadap perilaku turis muslim Indonesia dapat membantu menyusun strategi promosi yang mampu menarik wisatawan nusantara untuk mengunjungi destinasi wisata halal di dalam negeri.

Destinasi wisata halal dalam negeri yang menjadi fokus dalam penelitian ini adalah Lombok, Nusa Tenggara Barat. Lombok dapat dikatakan sebagai destinasi wisata halal unggulan dan percontohan di Indonesia. Sejak awal pengembangan pariwisata halal di Indonesia, Lombok telah menjadi satu dari tiga daerah utama yang disiapkan sebagai destinasi wisata halal dan telah berhasil memperoleh beragam penghargaan tingkat dunia (Hamzana, 2017). Lombok juga berhasil menjadi destinasi wisata halal terbaik di Indonesia pada tahun 2018 dan 2019 berdasarkan peringkat Crescentrating-Mastercard Indonesia Muslim Travel Index (IMTI) (Mastercard, 2019).

Di era digital ini, internet dan media sosial dapat menjadi sarana untuk mempromosikan destinasi wisata halal Lombok melalui electronic word-of-mouth karena semakin banyak turis yang mencari informasi wisata melalui internet (Miao, 2015). Electronic word-of-mouth (eWOM) merujuk pada segala komunikasi yang dilakukan oleh turis yang sedang atau telah mengunjungi suatu destinasi wisata mengenai destinasi tersebut atau mengenai produk, layanan, serta pengalaman di destinasi tersebut melalui platform komunikasi online, baik platform yang berbasis web maupun mobile, yang dapat diakses oleh banyak orang (Babić Rosario, de Valck, \& Sotgiu, 2020; Chu \& Kim, 2018; Ismagilova, Dwivedi, Slade, \& Williams, 2017; Kietzmann \& Canhoto, 2013; Williams, Inversini, Buhalis, \& Ferdinand, 2015).

eWOM merupakan pengembangan dari word-of-mouth (WOM) tradisional (Babić Rosario et al., 2020; Ismagilova et al., 2017; Mishra \& Satish, 2016). Komunikasi WOM dan eWOM memiliki konsep dasar yang sama, yaitu penyebaran informasi dari opinion leader atau individu yang memiliki pengetahuan mengenai suatu topik kepada opinion seeker atau individu yang mencari informasi atau saran ketika individu tersebut ingin membuat keputusan atau melakukan sesuatu (Sun, Youn, Wu, \& Kuntaraporn, 2006). Perbedaan WOM tradisional dan eWOM terdapat pada bentuk saluran komunikasi yang digunakan, yaitu WOM menggunakan ucapan lisan secara tatap muka, sedangkan eWOM menggunakan saluran komunikasi online, seperti blog, forum diskusi, dan media sosial dengan menggunakan berbagai bentuk multimedia, seperti teks, gambar, video, dan animasi (Mishra \& Satish, 2016; Sun et al., 2006).

Komunikasi eWOM telah terbukti berpengaruh signifikan terhadap sikap dan intensi turis untuk mengunjungi destinasi wisata halal (Fakharyan, Jalilvand, Elyasi, \& Mohammadi, 2012). Peranan penting eWOM dalam promosi destinasi wisata halal itu mendorong kebutuhan untuk memahami faktor-faktor yang akan memicu turis muslim melakukan eWOM setelah turis tersebut mengunjungi destinasi wisata halal. Penelitian-penelitian terdahulu di bidang pariwisata halal telah ada yang meneliti faktor-faktor yang mendorong turis melakukan WOM tradisional dengan mempertimbangkan pengalaman turis di destinasi itu dan nilai-nilai keagamaan dengan menggunakan variabel atribut pariwisata halal dan kepuasan (Wardi, Abror, \& Trinanda, 2018), serta religiositas, customer engagement, atribut pariwisata halal, dan kepuasan (Abror et al., 2021). Akan tetapi, penelitian-penelitian terdahulu tersebut tidak secara spesifik meneliti anteseden eWOM dan 
hanya melihat persepsi nilai dari aspek atribut pariwisata halal. Penelitian ini akan mengisi celah penelitian dengan fokus pada eWOM dan faktor-faktor anteseden berupa religiositas Islami, persepsi nilai dengan melihat pada aspek kualitas, harga, emosional, sosial, pengalaman baru, pengalaman berbeda, keamanan, lokasi, atribut fisik, dan atribut nonfisik, serta anteseden kepuasan destinasi.

Penelitian terhadap perilaku turis muslim dapat dimulai dengan pemahaman terhadap religiositas Islami yang dimiliki turis muslim. Religiositas Islami merupakan derajat keyakinan, ketaatan, dan komitmen seseorang terhadap ajaran, nilai, aturan, dan praktik agama Islam dalam kehidupannya (Al Abdulrazak \& Gbadamosi, 2017; Bukhari et al., 2019; Ilter, Bayraktaroglu, \& Ipek, 2017; Mohd Dali, Yousafzai, \& Abdul Hamid, 2019; Wahyoedi, 2017). Religiositas merefleksikan cara hidup individu dan masyarakat dalam bentuk nilai-nilai dan sikap-sikap yang kemudian membentuk perilaku dan praktik keseharian (Eid \& El-Gohary, 2015b). Tingkat religiositas yang dimiliki turis muslim memengaruhi pemahaman turis mengenai pariwisata halal dan memengaruhi persepsi turis tentang kebutuhan yang diperlukan di sebuah destinasi wisata (El-Gohary, 2016).

Kemampuan destinasi wisata untuk memenuhi keinginan turis muslim berpengaruh terhadap persepsi nilai turis muslim terhadap destinasi tersebut. Persepsi nilai merupakan evaluasi menyeluruh individu terhadap nilai-nilai dominan suatu produk atau layanan berdasarkan perbandingan antara hasil yang diharapkan dari interpretasi informasi mengenai atribut produk atau atribut performa, keuntungan yang diperoleh, dan pengorbanan yang dilakukan sebelum, ketika, dan setelah pembelian atau penggunaan (Al-Ansi \& Han, 2019; Eom \& Lu, 2019; Prajitmutita, Perényi, \& Prentice, 2016; Rasoolimanesh, Dahalan, \& Jaafar, 2016; Schoeman, Van der Merwe, \& Slabbert, 2016). Pemahaman terhadap persepsi nilai turis muslim dapat membantu memahami nilai-nilai penting yang dapat mendorong turis muslim untuk menyebarkan WOM positif (Sukaris, Hartini, \& Mardhiyah, 2020).

Eid dan El-Gohary (2015a) membuat instrumen pengukuran Muslim Tourist Perceived Value (MTPV) untuk mengevaluasi persepsi nilai turis muslim dari aspek dimensi nilai kognitif berupa kualitas dan harga, dimensi nilai afektif berupa emosional dan sosial, dan dimensi nilai Islami berupa atribut fisik dan atribut nonfisik. Dalam penelitian kualitatif yang dilakukan Rodrigo dan Turnbull (2019), keenam faktor tersebut juga muncul sebagai nilai yang dianggap penting oleh turis muslim yang menjadi narasumber. Selain itu, Rodrigo dan Turnbull (2019) juga menemukan empat nilai penting lain, yaitu pengalaman berbeda dan pengalaman baru dari dimensi nilai epistemik, serta faktor keamanan dan lokasi dari dimensi nilai kondisional. Penelitian ini melihat persepsi nilai turis muslim dari kesepuluh aspek tersebut.

Persepsi nilai berbeda dengan kepuasan konsumen karena persepsi nilai berkaitan dengan nilai yang diberikan oleh produk atau layanan kepada konsumen, sedangkan kepuasan berkaitan dengan pemenuhan kebutuhan-kebutuhan konsumen (Isa, Chin, \& Mohammad, 2018). Kepuasan destinasi dapat didefinisikan sebagai evaluasi secara keseluruhan yang bersifat subjektif dan emosional terhadap pengalaman menggunakan produk dan layanan di sebuah destinasi dibandingkan dengan kebutuhan dan ekspektasi (Al-Ansi \& Han, 2019; Chen \& Phou, 2013; Isa et al., 2018; Kumar, 2016; Su, Hsu, \& Swanson, 2017). Definisi tersebut mengindikasikan bahwa kepuasan turis terhadap sebuah destinasi dapat tercapai apabila destinasi tersebut dapat menyediakan produk dan layanan yang dibutuhkan oleh turis dan melebihi ekspektasi turis. Keberhasilan memberikan kepuasan kepada turis akan mendorong turis untuk merekomendasikan atau memberikan informasi positif mengenai destinasi wisata tersebut kepada orang lain (Wardi et al., 2018).

Terdapat penelitian-penelitian terdahulu yang dapat menjadi dasar dalam menganalisis hubungan religiositas Islami, persepsi nilai, dan kepuasan sebagai anteseden langsung dan tidak langsung eWOM. Dari penelitian-penelitian terdahulu tersebut, dapat dihipotesiskan keberadaan pengaruh tidak langsung religiositas terhadap eWOM dengan mediasi kepuasan (Abror et al., 2021), pengaruh religiositas terhadap persepsi nilai (Kusumawati, Listyorini, Suharyono, \& Yulianto, 2019), pengaruh persepsi nilai terhadap eWOM (Shaikh, Karjaluoto, \& Häkkinen, 2018; Sukaris et al., 2020), pengaruh persepsi nilai terhadap kepuasan (Eid \& El-Gohary, 2015b; Wardi et al., 2018), dan pengaruh kepuasan terhadap eWOM (Jridi, Chaabouni, Bakini, \& Harbaoui, 2018; Shaikh et al., 2018). 
Penelitian ini melengkapi penelitian-penelitian terdahulu tersebut dengan menggabungkan variabel religiositas Islami, persepsi nilai, kepuasan destinasi, dan eWOM dalam satu model analisis dan mengujinya dalam konteks pariwisata halal Lombok dengan objek turis muslim Indonesia. Penelitian ini bertujuan untuk memberikan gambaran mengenai hubungan pengaruh religiositas Islami, persepsi nilai, dan kepuasan destinasi terhadap eWOM, baik hubungan secara langsung, maupun melalui mediasi. Hubungan pertama yang dianalisis dalam penelitian ini adalah hubungan pengaruh langsung religiositas Islami, persepsi nilai, dan kepuasan destinasi terhadap eWOM. Analisis selanjutnya memeriksa keberadaan efek mediasi kepuasan destinasi dalam hubungan pengaruh religiositas Islami dan persepsi nilai terhadap eWOM, serta efek mediasi serial persepsi nilai dimensi nilai Islami dan kepuasan destinasi dalam hubungan pengaruh religiositas Islami terhadap eWOM. Melalui analisis tersebut, perbandingan pengaruh dimensi-dimensi persepsi nilai terhadap eWOM dapat dilakukan untuk menemukan dimensi persepsi nilai yang paling berpengaruh terhadap eWOM.

Perbedaan penelitian ini dari penelitian-penelitian terdahulu tersebut adalah penambahan pengujian pengaruh langsung religiositas Islami terhadap eWOM dan pengaruh tidak langsung religiositas Islami terhadap eWOM melalui mediasi serial persepsi nilai dan kepuasan destinasi. Selain itu, penelitian ini juga menambahkan persepsi nilai dimensi nilai epistemik dan nilai kondisional yang didasarkan pada penelitian kualitatif Rodrigo dan Turnbull (2019) ke dalam instrumen pengukuran Muslim Tourist Perceived Value (MTPV) milik Eid dan El-Gohary (2015b, 2015a). Dimensi-dimensi persepsi nilai tersebut akan diuji untuk menemukan dimensi yang paling berpengaruh terhadap eWOM.

\section{Hipotesis dan Model Penelitian}

\section{Pengaruh Religiositas Islami terhadap Persepsi Nilai}

Identitas keagamaan memegang peranan penting dalam membentuk pengalaman konsumsi konsumen karena ada ajaran agama yang memberikan pedoman perilaku yang dapat mendorong atau mencegah penganutnya melakukan suatu hal (Eid \& El-Gohary, 2015a). Nilai-nilai yang berkaitan dengan identitas keagamaan tersebut memengaruhi penilaian konsumen terhadap suatu produk dan layanan (Kusumawati et al., 2019). Konsumen yang memiliki tingkat religiositas yang tinggi akan memiliki persepsi yang baik terhadap produk dan layanan yang dapat memenuhi kebutuhan sesuai dengan nilai-nilai keagamaan yang dimiliki oleh konsumen tersebut (Kusumawati et al., 2019). Pemahaman turis muslim mengenai pariwisata halal dan persepsi turis muslim tentang kebutuhan yang diperlukan di sebuah destinasi wisata juga dipengaruhi oleh tingkat religiositas (El-Gohary, 2016). Persepsi nilai turis muslim yang didasarkan pada ketersediaan fasilitas untuk memenuhi kebutuhan keagamaan tersebut diukur dengan persepsi nilai dimensi nilai Islami yang terdiri atas atribut fisik dan atribut nonfisik (Eid \& El-Gohary, 2015a, 2015b). Berdasarkan argumen tersebut, dapat dirumuskan hipotesis penelitian 1 sebagai berikut:

H1a-H1b : Religiositas Islami berpengaruh terhadap atribut fisik (H1a) dan atribut nonfisik (H1b)

Pengaruh Religiositas Islami terhadap Kepuasan Destinasi

Turis muslim berharap penyedia layanan wisata dapat memenuhi ekspektasi religiositas turis (Rodrigo \& Turnbull, 2019). Ekspektasi religiositas setiap turis muslim dapat berbeda karena adanya perbedaan tingkat religiositas antarindividu. Perbedaan tersebut menyebabkan tidak semua muslim memiliki pemahaman yang sama tentang kebutuhan yang harus ada di destinasi wisata halal (ElGohary, 2016) sehingga ekspektasi turis muslim mengenai pemenuhan kebutuhan keagamaan di sebuah destinasi wisata pun berbeda-beda. Label "halal" berpengaruh signifikan dalam pengambilan keputusan wisata bagi turis muslim yang memiliki tingkat religiositas yang tinggi (Boğan \& Sarışık, 2019). Ketika turis muslim memilih sebuah destinasi wisata karena destinasi tersebut memiliki label sebagai "destinasi wisata halal", turis muslim tersebut berharap dapat melakukan aktivitas yang sesuai dengan ajaran agama Islam (Boğan \& Sarışık, 2019). Jika destinasi wisata tersebut dapat menyediakan 
kebutuhan keagamaan sesuai dengan ekspektasi, kemungkinan besar turis tersebut akan merasa puas. Argumen tersebut didukung oleh penelitian Abror dkk. (2021) yang menemukan bahwa religiositas turis muslim memengaruhi kepuasan turis terhadap destinasi wisata halal. Oleh karena itu, ditetapkan hipotesis penelitian 2 sebagai berikut:

H2 : Religiositas Islami berpengaruh terhadap kepuasan destinasi

Pengaruh Religiositas Islami terhadap eWOM

Religiositas memengaruhi preferensi dan perilaku konsumen muslim (Salam, Muhamad, \& Leong, 2019). Penelitian Abror dkk. (2021) menemukan bahwa tingkat religiositas turis muslim secara tidak langsung memengaruhi komunikasi WOM mengenai destinasi wisata halal melalui mediasi kepuasan. Akan tetapi, penelitian tersebut tidak menguji pengaruh langsung religiositas terhadap WOM. Yusoff dan Adzharuddin (2017) menyebutkan bahwa konsumen muslim yang memiliki kesadaran tinggi tentang kehalalan suatu produk akan secara aktif mencari informasi mengenai kehalalan produk tersebut dan kemudian akan membagikan informasi tersebut kepada orang-orang terdekat, seperti anggota keluarga. Kesadaran yang tinggi terhadap kehalalan produk menandakan bahwa konsumen tersebut memiliki komitmen religiositas yang tinggi (Ambali \& Bakar, 2014; Yusoff \& Adzharuddin, 2017). Berdasarkan argumen tersebut, hipotesis penelitian 3 ditetapkan sebagai berikut:

H3 : Religiositas Islami berpengaruh terhadap eWOM

Pengaruh Persepsi Nilai terhadap Kepuasan Destinasi

Eid dan El-Gohary (2015b) menemukan bahwa persepsi nilai yang dimiliki oleh turis muslim memengaruhi kepuasan. Temuan pengaruh tersebut diperkuat oleh hasil penelitian Azhani dkk. (2017) dan Isa dkk. (2018). Ketiga penelitian tersebut mengukur persepsi nilai turis muslim dengan pengukuran nilai yang sama, yaitu kualitas, harga, emosional, sosial, atribut fisik, dan atribut nonfisik. Penelitian ini mengembangkan instrumen pengukuran tersebut dengan menambahkan dua dimensi yang diadaptasi dari penelitian kualitatif Rodrigo dan Turnbull (2019), yaitu dimensi nilai epistemik yang terdiri atas pengalaman berbeda dan pengalaman baru, serta dimensi nilai kondisional yang terdiri atas keamanan dan lokasi. Dalam konteks dan objek penelitian yang berbeda, dapat terjadi perbedaan dimensi persepsi nilai yang berpengaruh signifikan terhadap kepuasan (Azhani et al., 2017; Eid \& El-Gohary, 2015b; Isa et al., 2018) sehingga perlu menganalisis pengaruh setiap dimensi persepsi nilai untuk melihat persepsi nilai mana yang berpengaruh dalam konteks penelitian tertentu. Oleh karena itu, ditetapkan hipotesis penelitian 4 sebagai berikut:

H4a-H4j : Atribut fisik (H4a), atribut nonfisik (H4b), kualitas (H4c), harga (H4d), emosional $(\mathrm{H} 4 \mathrm{e})$, sosial $(\mathrm{H} 4 \mathrm{f})$, pengalaman berbeda $(\mathrm{H} 4 \mathrm{~g})$, pengalaman baru $(\mathrm{H} 4 \mathrm{~h})$, keamanan (H4i), dan lokasi (H4j) berpengaruh terhadap kepuasan destinasi

Pengaruh Persepsi Nilai terhadap eWOM

Turis yang merasa sebuah destinasi dapat memberikan nilai-nilai yang diinginkan akan melakukan aktivitas eWOM mengenai pengalamannya di destinasi tersebut (Shaikh et al., 2018; Sukaris et al., 2020). Oleh karena itu hipotesis penelitian 5 ditetapkan sebagai berikut:

H5a-H5j : Atribut fisik (H5a), atribut nonfisik (H5b), kualitas (H5c), harga (H5d), emosional (H5e), sosial (H5f), pengalaman berbeda (H5g), pengalaman baru (H5h), keamanan (H5i), dan lokasi (H5j) berpengaruh terhadap eWOM

Pengaruh Kepuasan Destinasi terhadap eWOM

Banyak literatur terdahulu yang menemukan pengaruh kepuasan terhadap eWOM (Ismagilova et al., 2017; Jridi et al., 2018; Shaikh et al., 2018). Pengaruh tersebut juga terlihat dalam konteks pariwisata halal. Turis muslim yang merasa puas dengan sebuah destinasi wisata akan merekomendasikan atau memberitahukan informasi positif tentang destinasi tersebut kepada orang lain (Wardi et al., 2018). Meskipun demikian, terdapat juga penelitian-penelitian terdahulu yang menunjukkan bahwa kepuasan 
dapat juga tidak berpengaruh signifikan terhadap eWOM dalam konteks dan objek penelitian yang berbeda (Ismagilova et al., 2017; Serra-Cantallops, Ramón Cardona, \& Salvi, 2020; Yang, 2017). Oleh karena itu, pengaruh tersebut akan diteliti dengan hipotesis sebagai berikut:

H6 : Kepuasan destinasi berpengaruh terhadap eWOM

Model analisis penelitian beserta jalur yang dihipotesiskan dalam penelitian ini dapat dilihat pada Gambar 1.

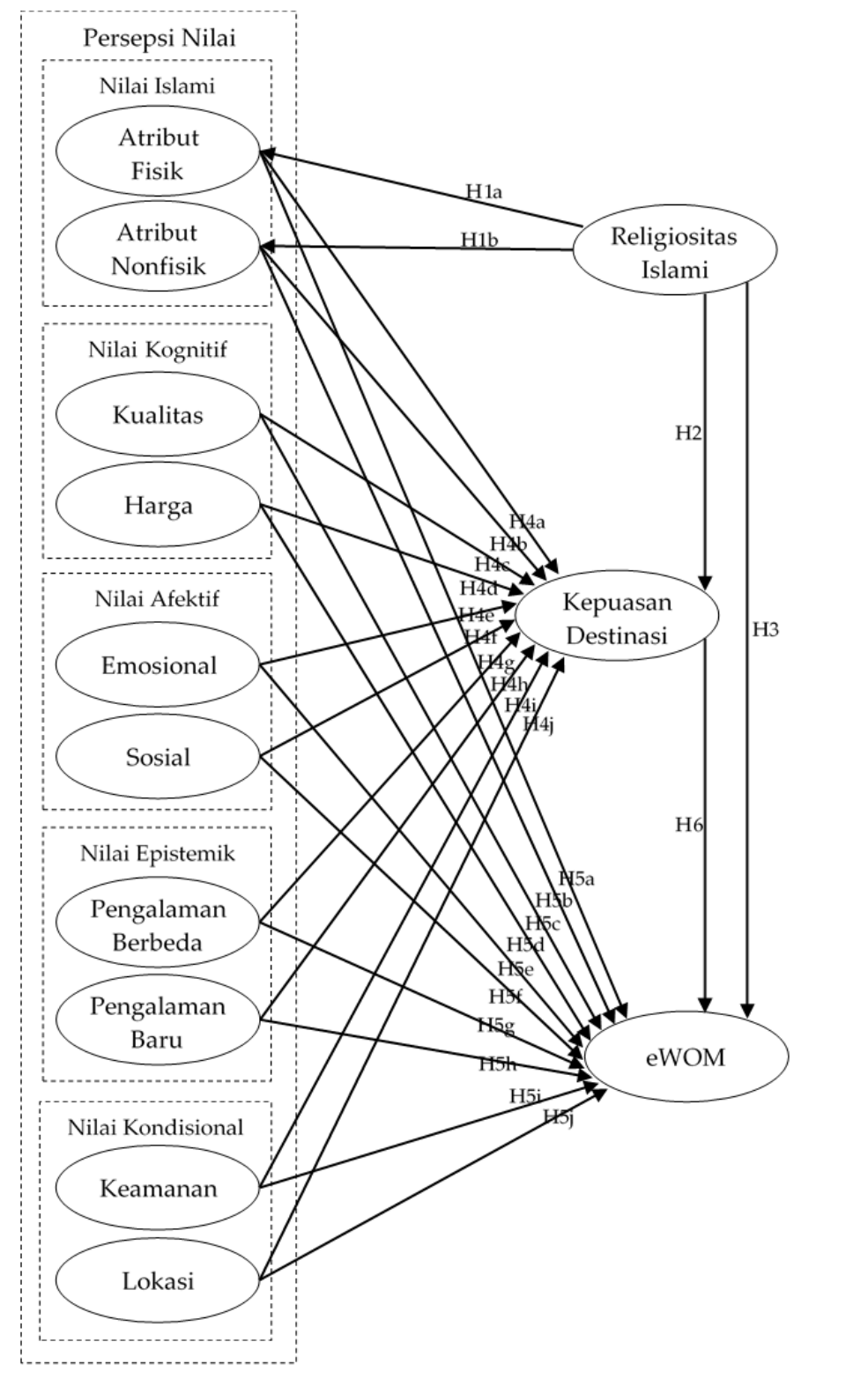

Gambar 1 Model Analisis Penelitian

\section{Metode Penelitian}

Pengumpulan Data

Penelitian ini menggunakan paradigma positivis dan metode kuantitatif. Data dikumpulkan melalui kuesioner online Google Form dengan kriteria responden adalah turis muslim Indonesia yang pernah mengunjungi destinasi wisata halal di Lombok, Nusa Tenggara Barat. Tidak terdapat kerangka sampel lengkap yang berisi data semua turis muslim Indonesia yang pernah mengunjungi destinasi wisata halal di Lombok sehingga pengambilan sampel menggunakan teknik sampling non- 
probabilitas dengan dua macam teknik, yaitu purposive sampling dan snowball sampling. Kuesioner disebarkan kepada responden yang sesuai dengan kriteria sampel melalui Instagram, Facebook, Twitter, situs forum, WhatsApp, dan Line. Penyebaran kuesioner dilakukan dengan membuat post / pengumuman di media sosial dan aplikasi chatting, memasang iklan di Instagram dan Facebook dengan kriteria target iklan adalah semua orang di Indonesia yang memiliki minat terhadap pariwisata halal atau Lombok, serta menghubungi pengguna Instagram yang pernah menggunakan tagar \#wisatahalallombok. Untuk menjangkau lebih banyak responden, teknik snowball sampling juga digunakan dalam penelitian ini dengan cara meminta kesediaan setiap responden untuk membantu menyebarkan kuesioner ke orang-orang yang responden nilai memenuhi kriteria sampel. Melalui cara itu, kuesioner dapat disebarkan dalam lingkaran sosial privat yang sebelumnya tidak terjangkau.

Untuk menarik partisipasi calon responden, terdapat undian hadiah OVO/GoPay sebesar Rp. 25.000 untuk 20 orang responden yang terpilih secara acak. Partisipasi responden dalam undian berhadiah tersebut bersifat sukarela sehingga responden dapat memilih untuk tidak memberitahu identitas berupa nama panggilan dan nomor telepon genggam jika ingin semua jawabannya bersifat anonim. Responden dapat mengisi sendiri kuesioner (self-administered). Untuk memastikan setiap responden memiliki kriteria yang sesuai, pada bagian awal kuesioner terdapat pertanyaanpertanyaan screening.

Ukuran sampel minimum penelitian ini mengikuti perhitungan berdasarkan kekuatan, ukuran efek yang diinginkan, dan kompleksitas model (Collier, 2020) menggunakan kalkulator online Soper (2020) dengan parameter ukuran efek 0.3, level kekuatan 0.8, jumlah variabel laten 13, jumlah indikator 66, dan level probabilitas 0.05 . Hasil kalkulasi menunjukkan jumlah sampel minimum yang direkomendasikan adalah 204. Pengumpulan data sampel akhir dilakukan pada tanggal 3 Oktober 2020 hingga 26 Oktober 2020. Selama rentang waktu tersebut, terdapat 408 kuesioner yang masuk. Setelah dilakukan pengolahan data awal, ditemukan 76 kuesioner yang tidak dapat dipakai sehingga data akhir berjumlah 332 .

\section{Instrumen Penelitian}

Instrumen pengukuran dalam penelitian ini merupakan adaptasi dan gabungan dari beberapa penelitian terdahulu. Pretest instrumen dilakukan terhadap 30 orang untuk memastikan validitas dan reliabilitas instrumen penelitian sebelum disebarkan untuk sampel akhir. Skala pengukuran menggunakan skala Likert dengan 5 skala poin. Variabel eksogen dalam penelitian ini adalah religiositas Islami, kualitas, harga, emosional, lokasi, keamanan, pengalaman baru, pengalaman berbeda, dan sosial, sedangkan variabel endogen adalah atribut fisik, atribut nonfisik, kepuasan destinasi, dan eWOM. Pengukuran variabel religiositas Islami mengadaptasi penelitian Eid dan El-Gohary (2015b) dengan menggunakan dua dimensi, yaitu keyakinan Islami (Kei) dan Praktik Islami (Pra). Pengukuran variabel-variabel persepsi nilai mengadaptasi penelitian Eid dan El-Gohary (2015a), Isa dkk. (2018), M. Battour dkk. (2011), dan Rodrigo dan Turnbull (2019). Pengukuran variabel kepuasan destinasi mengadaptasi penelitian Al-Ansi dan Han (2019), Chen dan Phou (2013), Isa dkk. (2018), Su dkk. (2017), dan V. Kumar (2016). Pengukuran variabel eWOM mengadaptasi penelitian Sukaris dkk. (2020).

\section{Analisis Data}

Penelitian ini menggunakan metode analisis Structural Equation Modeling (SEM) dengan pendekatan partial least squares (PLS-SEM) menggunakan software SmartPLS 3 (Ringle, Wende, \& Becker, 2015). Analisis PLS-SEM dilakukan dalam dua tahapan proses (Hair, Hult, Ringle, \& Sarstedt, 2017). Tahap pertama adalah analisis model pengukuran untuk menguji reliabilitas, validitas konvergen, dan validitas diskriminan. Uji reliabilitas dilakukan dengan melihat Cronbach's alpha $(\alpha)$ dan composite reliability (CR). Uji validitas konvergen dilakukan dengan melihat outer loadings dan Average Variance Extracted (AVE), sedangkan uji validitas diskriminan dilakukan dengan melihat nilai cross-loading, Fornell-Larcker criterion, dan rasio Heterotrait-Monotrait (HTMT). Tahap kedua adalah analisis model struktural untuk memeriksa isu kolinearitas model struktural, signifikansi dan relevansi hubungan, koefisien determinasi $\left(R^{2}\right)$, kekuatan efek $f^{2}$, relevansi prediktif $\left(Q^{2}\right)$, dan kekuatan efek $q^{2}$. 


\section{Hasil Penelitian}

\section{Profil Responden}

Mayoritas responden merupakan generasi $Y$ atau generasi Milenial yang lahir antara tahun 19801994 (54.2\%). Lebih dari setengah responden adalah perempuan (55.1\%). Sebagian besar responden berwisata di Lombok dalam rentang waktu kurang dari 1 tahun yang lalu (49.1\%) dan berasal dari luar Provinsi Nusa Tenggara Barat (62.3\%). Sebanyak 40.7\% responden menyatakan berwisata di dalam negeri sebanyak 1-3 kali dalam satu tahun dan 55.4\% menyatakan mengalokasikan anggaran sebesar 1.000.0001 - 5.000.000 untuk setiap perjalanan wisata per orang. Sebagian besar responden $(89.5 \%)$ mengaku sering membagikan informasi wisata dan / atau pengalaman berwisata ke orang lain.

\section{Analisis Model Pengukuran}

Di tahap ini, terdeteksi masalah pada validitas diskriminan antara variabel religiositas Islami dan dimensi-dimensinya. Untuk mengatasi hal tersebut, dilakukan respesifikasi model pengukuran dengan menggabungkan kedua dimensi tersebut sehingga variabel religiositas Islami menjadi variabel unidimensional. Uji reliabilitas dan validitas dilakukan kembali terhadap model hasil respesifikasi. Hasil uji memperlihatkan semua variabel memiliki nilai Cronbach's alpha dan composite reliability $>0.7$ sehingga model dinyatakan memiliki reliabilitas. Pemeriksaan outer loadings menunjukkan ada 3 indikator dengan nilai outer loadings $<0.7$, tetapi masih di rentang toleransi 0.40.70 di mana semua indikator memiliki AVE > 0.50 dan composite reliability > 0.7 (Hair et al., 2017) sehingga ketiga indikator tersebut masih dapat dipertahankan dan model dinyatakan memiliki validitas konvergen. Hasil analisis selanjutnya menunjukkan semua indikator memiliki nilai outer loadings yang lebih besar dari nilai cross-loadings terhadap konstruk mana pun. Hasil pengujian Fornell-Larcker Criterion menunjukkan nilai akar AVE dari setiap konstruk lebih besar dari nilai korelasi tertinggi terhadap konstruk mana pun. Pengujian terhadap HTMT menunjukkan semua nilai $<0.90$. Berdasarkan hasil tersebut, disimpulkan bahwa model juga telah memiliki validitas diskriminan.

\section{Analisis Model Struktural}

Pemeriksaan terhadap nilai inner VIF (Variance Inflation Factor) antarvariabel menunjukkan tidak ada masalah kolinearitas dalam model struktural (VIF < 5) sehingga analisis dapat dilanjutkan ke tahap pengujian hipotesis. Keputusan untuk menerima atau menolak hipotesis didasarkan pada nilai $t$-value $(>1.96)$ dan $p$-value $(<0.05)$ dari nilai koefisien jalur, serta mempertimbangkan nilai $R^{2}(\geq 0.25)$, $f^{2}$ ( $\geq 0.02), Q^{2}(>0)$, dan $q^{2}(\geq 0.02)$.

Hasil dari pemeriksaan koefisien jalur (Tabel 1) menunjukkan bahwa jalur yang dihipotesiskan dengan hipotesis H2, H3, H4a, H4b, H4j, H5a, H5b, H5c, H5d, H5e, H5g, H5h, H5j, H6 tidak memiliki signifikansi sehingga hipotesis-hipotesis tersebut ditolak. Sebelas jalur lainnya menunjukkan signifikansi, tetapi diperlukan analisis lanjutan terhadap nilai $R^{2}$ dan $Q^{2}$ untuk mengukur kekuatan prediktif model terhadap setiap variabel endogen yang diuji. Hasil pemeriksaan nilai $Q^{2}$ menunjukkan model memiliki kekuatan relevansi prediktif terhadap semua variabel endogen $\left(Q^{2}>0\right)$. Hasil analisis nilai $R^{2}$ menunjukkan bahwa model memiliki kekuatan prediktif medium terhadap kepuasan destinasi $\left(R^{2}=0.682\right)$ dan lemah terhadap eWOM $\left(R^{2}=0.451\right)$. Model tidak memiliki kekuatan prediktif $\left(R^{2}<0.25\right)$ terhadap atribut fisik $\left(R^{2}=0.095\right)$ dan nonfisik $\left(R^{2}=0.080\right)$ sehingga H1a dan H1b ditolak meskipun analisis koefisien jalur (Tabel 1) menunjukkan signifikansi jalur religiositas Islami terhadap atribut fisik dan atribut nonfisik.

Tabel 1. Hasil Pemeriksaan Koefisien Jalur, Nilai $f^{2}$, dan Nilai $q^{2}$

\begin{tabular}{|c|c|c|c|c|c|}
\hline Hipotesis & Jalur & $\begin{array}{c}\text { Koefisien } \\
\text { Jalur }\end{array}$ & t-value & $f^{2}$ & Hasil \\
\hline
\end{tabular}




\begin{tabular}{|c|c|c|c|c|c|c|}
\hline H1a & Religiositas Islami $\rightarrow$ atribut fisik & $0.309^{*}$ & 3.505 & 0.106 & -1071.428 & Ditolak \\
\hline $\mathrm{H} 1 \mathrm{~b}$ & Religiositas Islami $\rightarrow$ atribut nonfisik & $0.283^{*}$ & 5.215 & 0.087 & -1741.281 & Ditolak \\
\hline $\mathrm{H} 2$ & Religiositas Islami $\rightarrow$ kepuasan destinasi & -0.041 & 0.905 & 0.004 & 0.000 & Ditolak \\
\hline H3 & Religiositas Islami $\rightarrow$ eWOM & -0.016 & 0.341 & 0.000 & -0.002 & Ditolak \\
\hline $\mathrm{H} 4 \mathrm{a}$ & Atribut fisik $\rightarrow$ kepuasan destinasi & 0.009 & 0.111 & 0.000 & 0.000 & Ditolak \\
\hline $\mathrm{H} 4 \mathrm{~b}$ & Atribut nonfisik $\rightarrow$ kepuasan destinasi & 0.023 & 0.567 & 0.001 & 0.000 & Ditolak \\
\hline $\mathrm{H} 4 \mathrm{c}$ & Kualitas $\rightarrow$ kepuasan destinasi & $0.091^{*}$ & 2.155 & 0.015 & 0.005 & Ditolak \\
\hline $\mathrm{H} 4 \mathrm{~d}$ & Harga $\rightarrow$ kepuasan destinasi & $0.088^{*}$ & 2.031 & 0.016 & 0.006 & Ditolak \\
\hline $\mathrm{H} 4 \mathrm{e}$ & Emosional $\rightarrow$ kepuasan destinasi & $0.403^{*}$ & 5.374 & 0.205 & 0.087 & Diterima \\
\hline $\mathrm{H} 4 \mathrm{f}$ & Sosial $\rightarrow$ kepuasan destinasi & $0.094^{*}$ & 2.087 & 0.013 & 0.005 & Ditolak \\
\hline $\mathrm{H} 4 \mathrm{~g}$ & Pengalaman berbeda $\rightarrow$ kepuasan destinasi & $0.126^{*}$ & 2.689 & 0.013 & 0.009 & Ditolak \\
\hline $\mathrm{H} 4 \mathrm{~h}$ & Pengalaman baru $\rightarrow$ kepuasan destinasi & $0.152^{*}$ & 3.477 & 0.046 & 0.018 & Ditolak \\
\hline $\mathrm{H} 4 \mathrm{i}$ & Keamanan $\rightarrow$ kepuasan destinasi & $0.137^{*}$ & 2.771 & 0.023 & 0.009 & Ditolak \\
\hline $\mathrm{H} 4 \mathrm{j}$ & Lokasi $\rightarrow$ kepuasan destinasi & -0.027 & 0.701 & 0.001 & 0.000 & Ditolak \\
\hline $\mathrm{H} 5 \mathrm{a}$ & Atribut fisik $\rightarrow \mathrm{eWOM}$ & 0.088 & 1.287 & 0.007 & 0.000 & Ditolak \\
\hline $\mathrm{H} 5 \mathrm{~b}$ & Atribut nonfisik $\rightarrow \mathrm{eWOM}$ & -0.005 & 0.101 & 0.000 & -0.002 & Ditolak \\
\hline $\mathrm{H} 5 \mathrm{c}$ & Kualitas $\rightarrow$ eWOM & 0.026 & 0.372 & 0.001 & -0.004 & Ditolak \\
\hline $\mathrm{H} 5 \mathrm{~d}$ & Harga $\rightarrow$ eWOM & 0.109 & 1.763 & 0.014 & 0.003 & Ditolak \\
\hline $\mathrm{H} 5 \mathrm{e}$ & Emosional $\rightarrow \mathrm{eWOM}$ & 0.128 & 1.387 & 0.010 & 0.005 & Ditolak \\
\hline $\mathrm{H} 5 \mathrm{f}$ & Sosial $\rightarrow$ eWOM & $0.246^{*}$ & 3.462 & 0.052 & 0.028 & Diterima \\
\hline $\mathrm{H} 5 \mathrm{~g}$ & Pengalaman berbeda $\rightarrow \mathrm{eWOM}$ & 0.068 & 0.933 & 0.004 & -0.002 & Ditolak \\
\hline $\mathrm{H} 5 \mathrm{~h}$ & Pengalaman baru $\rightarrow$ eWOM & -0.021 & 0.386 & 0.000 & -0.003 & Ditolak \\
\hline $\mathrm{H} 5 \mathrm{i}$ & Keamanan $\rightarrow \mathrm{eWOM}$ & $0.207^{*}$ & 2.664 & 0.029 & 0.016 & Ditolak \\
\hline $\mathrm{H} 5 \mathrm{j}$ & Lokasi $\rightarrow \mathrm{eWOM}$ & -0.069 & 1.249 & 0.005 & 0.003 & Ditolak \\
\hline $\mathrm{H} 6$ & Kepuasan destinasi $\rightarrow$ eWOM & 0.074 & 0.804 & 0.003 & 0.001 & Ditolak \\
\hline
\end{tabular}

Catatan: *signifikan dengan $p$-value $>0.05$, two-tailed test

Tahap selanjutnya adalah memeriksa nilai $f^{2}$ untuk melihat kekuatan efek variabel eksogen terhadap variabel endogen dan nilai $q^{2}$ untuk melihat pengaruh relatif variabel eksogen terhadap nilai $Q^{2}$ variabel endogen. Hipotesis dapat diterima jika nilai $f^{2}$ dan $q^{2} \geq 0.02$. Hasil pemeriksaan nilai $f^{2}$ dan $q^{2}$ (Tabel 1) menunjukkan bahwa hipotesis H4c, H4d, H4f, H4g, H4h, H4i, dan H5f tidak memenuhi kriteria sehingga harus ditolak.

Dari hasil pengujian hipotesis di atas, terlihat bahwa hanya hipotesis H4e dan $\mathbf{H 5 f}$ yang memenuhi kriteria dan dapat diterima. Kedua jalur tersebut tidak terhubung satu sama lain sehingga terbentuk dua model fit akhir yang terpisah dengan variabel dependen yang berbeda, yaitu Model A dengan variabel dependen kepuasan destinasi dan Model B dengan variabel dependen eWOM (Gambar 2).

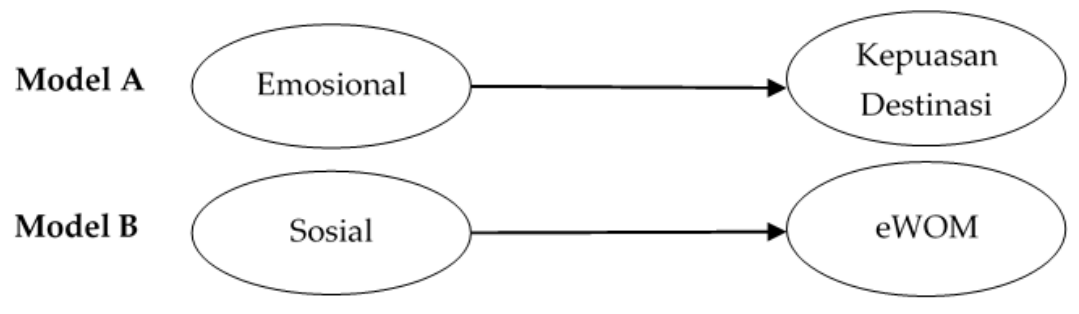

Gambar 2 Model Akhir

\section{Diskusi}

Hasil analisis menunjukkan bahwa tingkat religiositas turis muslim Indonesia tidak memengaruhi persepsi nilai terhadap atribut fisik dan atribut nonfisik di destinasi wisata halal Lombok. Religiositas Islami juga tidak berpengaruh terhadap kepuasan destinasi dan tidak mendorong turis muslim untuk melakukan komunikasi eWOM. Hal tersebut berbeda dengan hasil penelitian-penelitian terdahulu yang menemukan bahwa religiositas memengaruhi persepsi nilai 
(Kusumawati et al., 2019) dan kepuasan (Abror et al., 2021), serta mendorong orang untuk merekomendasikan suatu produk (Yusoff \& Adzharuddin, 2017). Perbedaan tersebut dapat diakibatkan oleh kecenderungan turis muslim Indonesia untuk tidak terlalu kritis terhadap aspek kehalalan produk-produk wisata di Indonesia (Hamzana, 2017; Pratiwi et al., 2018). Destinasi wisata halal Lombok berada di wilayah Indonesia yang berpenduduk mayoritas muslim sehingga turis muslim Indonesia mungkin menganggap ketersediaan fasilitas halal yang sesuai dengan nilai-nilai Islami di Lombok merupakan hal yang lazim dan bukan merupakan suatu hal yang istimewa.

Nilai-nilai dari destinasi wisata halal Lombok yang dianggap penting oleh turis muslim Indonesia dapat dilihat dari dimensi persepsi nilai yang berpengaruh terhadap kepuasan destinasi. Hasil analisis menunjukkan bahwa hanya emosional yang memiliki pengaruh signifikan. Persepsi nilai bersifat subjektif dan dinamis sehingga evaluasi nilai yang dianggap penting itu sangat bergantung pada pihak yang menilai dan objek yang dinilai (Eid \& El-Gohary, 2015a; Isa et al., 2018). Penelitian-penelitian terdahulu (Azhani et al., 2017; Eid \& El-Gohary, 2015b; Isa et al., 2018) menunjukkan bahwa perbedaan konteks dan objek penelitian dapat menyebabkan perbedaan dimensi persepsi nilai yang berpengaruh terhadap kepuasan turis muslim. Hasil penelitian ini menunjukkan bahwa dalam konteks pariwisata halal di Lombok, turis muslim Indonesia merasa puas terhadap destinasi wisata halal Lombok jika destinasi tersebut dapat memunculkan perasaan nyaman, relaks, positif, dan senang. Aspek-aspek di destinasi wisata halal Lombok selain aspek emosional tidak menjadi penilaian yang penting bagi turis muslim Indonesia karena mungkin aspekaspek tersebut tidak memiliki perbedaan yang signifikan dengan aspek-aspek di daerah-daerah lain di Indonesia sehingga aspek-aspek tersebut tidak menjadi nilai yang menonjol dan tidak menjadi kebutuhan yang penting saat berwisata di Lombok.

Hasil analisis selanjutnya menunjukkan bahwa persepsi nilai yang dapat memengaruhi kepuasan destinasi turis muslim Indonesia, yaitu emosional, tidak berarti menjadi persepsi nilai yang juga dapat mendorong turis muslim untuk melakukan eWOM. Dari hasil analisis terlihat bahwa hanya sosial yang berpengaruh signifikan terhadap eWOM. Persepsi nilai afektif sosial berkaitan dengan persepsi turis muslim mengenai penerimaan dan pengakuan sosial yang akan didapatkan jika turis melakukan sesuatu (Eid \& El-Gohary, 2015b). Temuan signifikansi pengaruh sosial terhadap eWOM tersebut dapat diartikan bahwa turis muslim memiliki kecenderungan melakukan komunikasi eWOM jika turis memersepsikan orang-orang di lingkungan sosial turis memiliki penilaian yang baik terhadap destinasi wisata halal di Lombok dan terhadap orang yang pernah berwisata di Lombok. Hasil itu sejalan dengan hasil penelitian Meuthia (2019) yang menemukan bahwa partisipasi turis untuk saling berdiskusi dan berbagi informasi tentang destinasi wisata halal akan meningkat jika teman-teman di media sosial turis memiliki ketertarikan yang sama terhadap destinasi wisata halal.

Temuan lain dalam penelitian ini adalah kepuasan destinasi tidak berpengaruh signifikan terhadap eWOM. Hasil tersebut berbeda dengan penelitian-penelitian terdahulu (Jridi et al., 2018; Shaikh et al., 2018) yang menemukan pengaruh signifikan kepuasan terhadap eWOM. Perbedaan temuan tersebut dapat diakibatkan oleh perbedaan konteks penelitian (Ismagilova et al., 2017; SerraCantallops et al., 2020). Penelitian Jridi dkk. (2018) dilakukan terhadap pengguna bank syariah, sedangkan penelitian Shaikh dkk. (2018) dilakukan terhadap pelanggan toko retail. Dalam konteks pariwisata halal, terdapat penelitian-penelitian terdahulu yang menemukan bahwa kepuasan mendorong orang untuk merekomendasikan destinasi wisata halal (Abror et al., 2021; Wardi et al., 2018), namun rekomendasi tersebut dilakukan melalui saluran WOM tradisional, bukan melalui saluran elektronik atau eWOM. Hasil penelitian ini menunjukkan bahwa kepuasan destinasi tidak mendorong turis muslim Indonesia melakukan komunikasi eWOM mengenai destinasi wisata halal.

Berdasarkan pemaparan di atas, terlihat bahwa hanya persepsi nilai sosial yang berpengaruh signifikan terhadap eWOM. Penyebab nilai sosial menjadi faktor tunggal yang mendorong turis muslim Indonesia untuk melakukan eWOM dapat dikaitkan dengan karakteristik responden penelitian ini yang mayoritas lahir di antara tahun 1980-1994 atau termasuk generasi milenial (Generasi Y). Milenial memanfaatkan komunikasi eWOM untuk mengonstruksi citra diri dalam 
platform online dengan cara membuat dan membagikan konten yang dianggap dapat menciptakan impresi yang sesuai dengan citra diri yang diinginkan (Kim, Jang, \& Adler, 2015). Milenial membuat konten eWOM yang dapat menjadi representasi identitas individual di dunia digital sekaligus identitas kelompok yang diinginkan.

Potensi keuntungan sosial yang dapat diperoleh melalui konten di media sosial menjadi pertimbangan milenial untuk melakukan komunikasi eWOM (Kim et al., 2015). Keuntungan sosial tersebut berkaitan dengan nilai diri dan impresi citra diri ideal yang terbangun di hadapan orang lain di media sosial. Jika milenial merasa tidak mendapatkan keuntungan sosial, milenial tidak akan melakukan komunikasi eWOM mengenai pengalaman konsumsi yang dialami, meskipun pengalaman tersebut adalah pengalaman positif. Selain itu, identifikasi diri terhadap kelompok tertentu yang diinginkan juga menjadi pertimbangan milenial untuk melakukan komunikasi eWOM. Ketika milenial dalam lingkungan sosial yang memiliki ketertarikan yang sama, milenial akan melakukan komunikasi eWOM terkait topik tersebut (Meuthia, 2019).

Hal tersebut mengindikasikan bahwa faktor usia dapat memengaruhi tingkat signifikansi pengaruh suatu faktor dalam mendorong turis muslim untuk melakukan eWOM. Mayoritas responden penelitian ini adalah milenial dan hasil penelitian ini memiliki kesesuaian dengan karakteristik generasi milenial yang menjadikan nilai sosial sebagai pertimbangan penting dalam melakukan eWOM. Turis muslim dari generasi milenial akan melakukan komunikasi eWOM mengenai pengalaman berwisata di destinasi wisata halal apabila turis tersebut memiliki keinginan untuk mengidentifikasikan diri dengan topik pariwisata halal dan memiliki lingkungan sosial atau kelompok yang juga memiliki ketertarikan terhadap pariwisata halal. Namun, jika turis muslim milenial merasa tidak mendapatkan keuntungan sosial dari komunikasi eWOM tersebut, turis tidak akan melakukan komunikasi eWOM tentang pengalaman wisata di destinasi wisata halal, meskipun turis memiliki persepsi yang baik dan kepuasan yang tinggi terhadap destinasi wisata halal tersebut.

Penelitian ini memiliki keterbatasan, yaitu penggunaan teknik pengambilan sampel nonprobabilitas sehingga hasil penelitian tidak dapat digeneralisasi dan hanya dapat mewakili sampel yang digunakan dalam penelitian ini. Penelitian ini hanya dilakukan terhadap turis muslim Indonesia yang pernah berwisata halal di Lombok dengan profil usia mayoritas adalah generasi Milenial. Perbedaan konteks dan objek penelitian dapat memengaruhi hasil sehingga kedua hal tersebut perlu menjadi pertimbangan dalam memahami hasil penelitian ini dan dalam penyusunan penelitian selanjutnya.

\section{Kesimpulan}

Signifikansi pengaruh suatu faktor pendorong terhadap eWOM dapat berbeda tergantung konteks dan objek penelitian. Penelitian ini menemukan bahwa dalam konteks pariwisata halal di Lombok dengan objek penelitian turis muslim Indonesia yang mayoritas berasal dari generasi milenial, faktor pendorong turis muslim Indonesia untuk melakukan eWOM tentang destinasi wisata halal di Lombok adalah faktor persepsi nilai sosial yang berkaitan dengan keinginan untuk membentuk identitas individu dan kelompok yang berhubungan dengan topik pariwisata halal di dunia virtual. Konteks asal turis muslim dan lokasi destinasi wisata halal juga menjadi hal yang perlu diperhatikan dalam memahami pengaruh faktor pendorong eWOM. Kesamaan karakteristik asal turis dan lokasi destinasi wisata dapat mengurangi signifikansi pengaruh suatu faktor. Bagi turis muslim Indonesia, faktor-faktor yang berkaitan dengan religiositas dan atribut-atribut kehalalan bukan merupakan faktor pendorong untuk melakukan eWOM mengenai destinasi wisata halal di dalam negeri. Mayoritas penduduk Indonesia yang beragama Islam membuat keberadaan atributatribut kehalalan tersebut dianggap sebagai hal yang biasa ada di destinasi wisata di Indonesia sehingga hal itu tidak menjadi faktor pendorong yang signifikan. 


\section{Referensi}

Abror, A., Patrisia, D., Trinanda, O., Omar, M. W., \& Wardi, Y. (2021). Antecedents of word of mouth in Muslimfriendly tourism marketing: the role of religiosity. Journal of Islamic Marketing, 12(4), 882-899. https://doi.org/10.1108/JIMA-01-2020-0006

Al-Ansi, A., \& Han, H. (2019). Role of halal-friendly destination performances, value, satisfaction, and trust in generating destination image and loyalty. Journal of Destination Marketing E Management, 13(May 2019), 5160. https://doi.org/10.1016/j.jdmm.2019.05.007

Al Abdulrazak, R. M., \& Gbadamosi, A. (2017). Trust, religiosity, and relationship marketing: a conceptual overview of consumer brand loyalty. Society and Business Review, 12(3), 320-339. https://doi.org/10.1108/SBR-03-2017-0014

Ambali, A. R., \& Bakar, A. N. (2014). People's Awareness on Halal Foods and Products: Potential Issues for Policy-makers. Procedia - Social and Behavioral Sciences, 121(2014), 3-25. https://doi.org/10.1016/j.sbspro.2014.01.1104

Azhani, M. A. N., Zainab, K., \& Hairul, N. I. (2017). Perceived Value and Satisfaction towards Shariah-Compliant Hotel. Pertanika Journal of Social Science and Humanities, 25, 77-88.

Babić Rosario, A., de Valck, K., \& Sotgiu, F. (2020). Conceptualizing the electronic word-of-mouth process: What we know and need to know about eWOM creation, exposure, and evaluation. Journal of the Academy of Marketing Science, 48(3), 422-448. https://doi.org/10.1007/s11747-019-00706-1

Battour, M., \& Ismail, M. N. (2016). Halal tourism: Concepts, practises, challenges and future. Tourism Management Perspectives, 19, 150-154. https://doi.org/10.1016/j.tmp.2015.12.008

Battour, M., Ismail, M. N., \& Battor, M. (2011). The Impact of Destination Attributes on Muslim Tourist's Choice. International Journal of Tourism Research, 13(6), 527-540. https://doi.org/10.1002/jtr.824

Boğan, E., \& Sarışık, M. (2019). Halal tourism: conceptual and practical challenges. Journal of Islamic Marketing, 10(1), 87-96. https://doi.org/10.1108/JIMA-06-2017-0066

Bukhari, S. F. H., Woodside, F. M., Hassan, R., Shaikh, A. L., Hussain, S., \& Mazhar, W. (2019). Is religiosity an important consideration in Muslim consumer behavior. Journal of Islamic Marketing, 10(4), 1288-1307. https://doi.org/10.1108/JIMA-01-2018-0006

Chen, C.-F., \& Phou, S. (2013). A closer look at destination: Image, personality, relationship and loyalty. Tourism Management, 36, 269-278. https://doi.org/10.1016/j.tourman.2012.11.015

Chu, S.-C., \& Kim, J. (2018). The current state of knowledge on electronic word-of-mouth in advertising research. International Journal of Advertising, 37(1), 1-13. https://doi.org/10.1080/02650487.2017.1407061

Collier, J. E. (2020). Applied Structural Equation Modeling Using AMOS: Basic to Advanced Techniques. New York: Routledge. https://doi.org/10.4324/9781003018414

Eid, R., \& El-Gohary, H. (2015a). Muslim Tourist Perceived Value in the Hospitality and Tourism Industry. Journal of Travel Research, 54(6), 774-787. https://doi.org/10.1177/0047287514532367

Eid, R., \& El-Gohary, H. (2015b). The role of Islamic religiosity on the relationship between perceived value and tourist satisfaction. Tourism Management, 46, 477-488. https://doi.org/10.1016/j.tourman.2014.08.003

El-Gohary, H. (2016). Halal tourism, is it really Halal? Tourism Management Perspectives, 19, $124-130$. https://doi.org/10.1016/j.tmp.2015.12.013

Eom, H. J., \& Lu, Z. (Laura). (2019). Establishing the measurement invariance in measures of consumers' perceived value. Asia Pacific Journal of Marketing and Logistics, 32(5), 1055-1069. https://doi.org/10.1108/APJML-03-2019-0135

Fakharyan, M., Jalilvand, M. R., Elyasi, M., \& Mohammadi, M. (2012). The influence of online word of mouth communications on tourists' attitudes toward Islamic destinations and travel intention: Evidence from Iran. African Journal of Business Management, 6(38), 10381-10388. https://doi.org/10.5897/AJBM12.628

Hair, J. F., Hult, G. T. M., Ringle, C. M., \& Sarstedt, M. (2017). A Primer on Partial Least Squares Structural Equation Modeling (PLS-SEM) (2 ed.). Los Angeles: Sage.

Hamzana, A. A. (2017). Pelaksanaan Standarisasi Pelayanan Pariwisata Halal dalam Pengembangan Pariwisata di Nusa Tenggara Barat. Pena Justisia: Media Komunikasi dan Kajian Hukum, 17(2), 1-16. https://doi.org/10.31941/pj.v17i2.545

Ilter, B., Bayraktaroglu, G., \& Ipek, I. (2017). Impact of Islamic religiosity on materialistic values in Turkey. Journal of Islamic Marketing, 8(4), 533-557. https://doi.org/10.1108/JIMA-12-2015-0092

Isa, S. M., Chin, P. N., \& Mohammad, N. U. (2018). Muslim tourist perceived value: a study on Malaysia Halal tourism. Journal of Islamic Marketing, 9(2), 402-420. https://doi.org/10.1108/JIMA-11-2016-0083

Ismagilova, E., Dwivedi, Y. K., Slade, E., \& Williams, M. D. (2017). Electronic Word of Mouth (eWOM) in the Marketing Context: A State of the Art Analysis and Future Directions. In SpringerBriefs in Business. 
SpringerBriefs in Business. Cham: Springer Nature. https://doi.org/10.1007/978-3-319-52459-7

Jridi, K., Chaabouni, A., Bakini, F., \& Harbaoui, M. (2018). The effect of service quality and religiosity on electronic word of mouth through satisfaction in Islamic banking in North Africa. International Journal of Islamic Marketing and Branding, 3(4), 278-298. https://doi.org/10.1504/IJIMB.2018.10019917

Kietzmann, J., \& Canhoto, A. (2013). Bittersweet! Understanding and Managing Electronic Word of Mouth. Journal of Public Affairs, 13(2), 146-159. https://doi.org/10.1002/pa.1470

Kim, D., Jang, S. (Shawn), \& Adler, H. (2015). What drives café customers to spread eWOM? International Journal of Contemporary Hospitality Management, 27(2), 261-282. https://doi.org/10.1108/IJCHM-06-2013-0269

Kumar, V. (2016). Examining the role of destination personality and self-congruity in predicting tourist behavior. Tourism Management Perspectives, 20, 217-227. https://doi.org/10.1016/j.tmp.2016.09.006

Kusumawati, A., Listyorini, S., Suharyono, S., \& Yulianto, E. (2019). The impact of religiosity on fashion knowledge, consumer-perceived value and patronage intention. Research Journal of Textile and Apparel, 23(4), 269-290. https://doi.org/10.1108/RJTA-04-2019-0014

Mastercard. (2019). Indonesia Muslim Travel Index (IMTI) 2019. Singapore.

Meuthia, M. (2019). Penentu Perilaku Berbagi Pengetahuan melalui Media Sosial: Persepsi Wisatawan pada Wisata Halal di Sumatera Barat. Procuratio: Jurnal Ilmiah Manajemen, 7(4), 364-378.

Miao, Y. (2015). The Influence of Electronic-WOM on Tourists' Behavioral Intention to Choose a Destination: A case of Chinese Tourists Visiting Thailand. AU-GSB e-JOURNAL, 8(1), 13-31.

Mishra, A., \& Satish, S. M. (2016). eWOM: Extant Research Review and Future Research Avenues. Vikalpa: The Journal for Decision Makers, 41(3), 222-233. https://doi.org/10.1177/0256090916650952

Mohd Dali, N. R. S., Yousafzai, S., \& Abdul Hamid, H. (2019). Religiosity scale development. Journal of Islamic Marketing, 10(1), 227-248. https://doi.org/10.1108/JIMA-11-2016-0087

Prajitmutita, L. M., Perényi, Á., \& Prentice, C. (2016). Quality, Value? - Insights into Medical Tourists' Attitudes and Behaviors. Journal of Retailing and Consumer Services, 31, 207-216. https://doi.org/10.1016/j.jretconser.2016.04.005

Pratiwi, S. R., Dida, S., \& Sjafirah, N. A. (2018). Strategi Komunikasi dalam Membangun Awareness Wisata Halal di Kota Bandung. Jurnal Kajian Komunikasi, 6(1), 78-90. https://doi.org/10.24198/jkk.v6i1.12985

Rasoolimanesh, S. M., Dahalan, N., \& Jaafar, M. (2016). Tourists' perceived value and satisfaction in a community-based homestay in the Lenggong Valley World Heritage Site. Journal of Hospitality and Tourism Management, 26, 72-81. https://doi.org/10.1016/j.jhtm.2016.01.005

Ringle, C. M., Wende, S., \& Becker, J.-M. (2015). SmartPLS 3. Boenningstedt: SmartPLS GmbH.

Rodrigo, P., \& Turnbull, S. (2019). Halal holidays: How is value perceived by Muslim tourists? International Journal of Tourism Research, 21(5), 675-692. https://doi.org/10.1002/jtr.2290

Salam, M. T., Muhamad, N., \& Leong, V. S. (2019). Measuring religiosity among Muslim consumers: observations and recommendations. Journal of Islamic Marketing, 10(2), 633-652. https://doi.org/10.1108/JIMA-02-20180038

Samori, Z., Md Salleh, N. Z., \& Khalid, M. M. (2016). Current trends on Halal tourism: Cases on selected Asian countries. Tourism Management Perspectives, 19, 131-136. https://doi.org/10.1016/j.tmp.2015.12.011

Schoeman, K., Van der Merwe, P., \& Slabbert, E. (2016). The Perceived Value of a Scuba Diving Experience. Journal of Coastal Research, 321, 1071-1080. https://doi.org/10.2112/JCOASTRES-D-15-00140.1

Serra-Cantallops, A., Ramón Cardona, J., \& Salvi, F. (2020). Antecedents of positive eWOM in hotels. Exploring the relative role of satisfaction, quality and positive emotional experiences. International Journal of Contemporary Hospitality Management, 32(11), 3457-3477. https://doi.org/10.1108/IJCHM-02-2020-0113

Shaikh, A. A., Karjaluoto, H., \& Häkkinen, J. (2018). Understanding moderating effects in increasing share-ofwallet and word-of-mouth: A case study of Lidl grocery retailer. Journal of Retailing and Consumer Services, 44, 45-53. https://doi.org/10.1016/j.jretconser.2018.05.009

Soper, D. S. (2020). A-priori Sample Size Calculator for Structural Equation Models. Diambil 29 Agustus 2020, dari Free Statistics Calculators website: https://www.danielsoper.com/statcalc/calculator.aspx?id=89

Su, L., Hsu, M. K., \& Swanson, S. (2017). The Effect of Tourist Relationship Perception on Destination Loyalty at a World Heritage Site in China: The Mediating Role of Overall Destination Satisfaction and Trust. Journal of Hospitality \& Tourism Research, 41(2), 180-210. https://doi.org/10.1177/1096348014525630

Sukaris, S., Hartini, S., \& Mardhiyah, D. (2020). The effect of perceived value by the tourists toward electronic word of mouth activity: the moderating role of conspicuous tendency. Jurnal Siasat Bisnis, 24(1), 1-17. https://doi.org/10.20885/jsb.vol24.iss1.art1

Sun, T., Youn, S., Wu, G., \& Kuntaraporn, M. (2006). Online Word-of-Mouth (or Mouse): An Exploration of Its Antecedents and Consequences. Journal of Computer-Mediated Communication, 11(4), 1104-1127. https://doi.org/10.1111/j.1083-6101.2006.00310.x 
Wahyoedi, S. (2017). The Effect of Religiosity, Service Quality, and Trust on Customer Loyalty in Islamic Banking in Bogor Indonesia. International Review of Management and Business Research, 6(1), 331-340.

Wardi, Y., Abror, A., \& Trinanda, O. (2018). Halal tourism: antecedent of tourist's satisfaction and word of mouth (WOM). Asia Pacific Journal of Tourism Research, 23(5), 463-472. https://doi.org/10.1080/10941665.2018.1466816

Williams, N. L., Inversini, A., Buhalis, D., \& Ferdinand, N. (2015). Community crosstalk: an exploratory analysis of destination and festival eWOM on Twitter. Journal of Marketing Management, 31(9-10), 1113-1140. https://doi.org/10.1080/0267257X.2015.1035308

Yang, F. X. (2017). Effects of Restaurant Satisfaction and Knowledge Sharing Motivation on eWOM Intentions: the Moderating Role of Technology Acceptance Factors. Journal of Hospitality \& Tourism Research, 41(1), 93127. https://doi.org/10.1177/1096348013515918

Yusoff, S. Z., \& Adzharuddin, N. A. (2017). Factor of Awareness in Searching and Sharing of Halal Food Product among Muslim Families in Malaysia. In B. Mohamad \& H. Abu Bakar (Ed.), SHS Web of Conferences (Vol. 33, hal. 00075). https://doi.org/10.1051/shsconf/20173300075

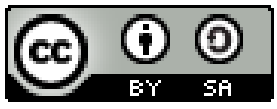

(C) 2021 by the authors. Submitted for possible open access publication under the terms and conditions of the Creative Commons Attribution (CC BY SA) license (https://creativecommons.org/licenses/by-sa/3.0/). 